\title{
DIVERGING DISPARITIES: RACE, PARENTAL INCOME, AND CHILDREN'S MATH SCORES, 1960-20091
}

\author{
Jordan A. Conwell \\ Assistant Professor \\ University of Wisconsin-Madison
}

Forthcoming, Sociology of Education

(Near-final manuscript; July 29, 2020 version)

\section{Citation:}

Conwell, Jordan A. Forthcoming. "Diverging Disparities: Race, Parental Income, and Children's Math Scores, 1960-2009." Sociology of Education.

1 For constructive feedback throughout the course of this project, I thank Eric Grodsky, Simone Ispa-Landa, Rourke O’Brien, Jayanti Owens, Brian Powell, Natasha Quadlin, Jim Rosenbaum, Quincy Stewart, and audiences at the 2017 Midwest Sociology of Education Conference, the 2018 American Sociological Association Annual Meeting, and the University of CaliforniaDavis Center for Research on Poverty. In the 2016-2017 academic year, work on this project was supported by a National Academy of Education/ Spencer Dissertation Fellowship. Direct correspondence to Jordan Conwell 4448, Sewell Social Sciences, 1180 Observatory Drive Madison, WI, 53706, USA (jaconwell@wisc.edu).

Data availability: data from Project TALENT and High School and Beyond are publicly available. This study relied on a restricted-use version of data from the High School Longitudinal Study, available via agreement with the National Center for Education Statistics. 


\section{DIVERGING DISPARITIES: RACE, PARENTAL INCOME, AND CHILDREN'S MATH SCORES, 1960-2009}

In recent decades, the Black-White test score disparity has decreased, while the test score disparity between children of high- versus low-income parents has increased. This study focuses on a comparison that has, to date, fallen between the separate literatures on these diverging trends - Black and White students whose parents have similarly low, middle, or high incomes (i.e., same-income or race-within-income). To do so, I draw on three nationally representative datasets on ninth or tenth graders, covering the period from 1960 to 2009, all of which contain information on students' math test scores. I find that math test score disparities between Black and White students with same-income parents are to Blacks' disadvantage. Although these disparities have decreased since 1960 , in 2009 , they remain substantively large, statistically significant, and largest between children of the highest income parents. Further, family and school characteristics that scholars commonly use to explain test score disparities by race or by income have accounted for markedly decreasing shares of race-within-income disparities over time. The study integrates the literatures on test score disparities by race and by income with needed attention to race's historical and continued structural influence, net of parental income, on students' educational experiences and test score outcomes.

Keywords: race, income, achievement gaps, inequality, intersectionality 
Disparities in students' test score outcomes have been central to research in the sociology of education since at least the Equality of Educational Opportunity report (Coleman et al. 1966). Notably, since the mid-twentieth century, outcome disparities across two key dimensions - race and parental income - have trended in the opposite directions. Disparities between Black and White children have substantially decreased (e.g., Magnuson and Waldfogel 2008; Reardon, Robinson-Cimpian, and Weathers 2014), while disparities between the children of high- versus low-income parents have substantially increased (Reardon 2011).

Divergent trends of test score disparities by race and by parental income have become a central stylized fact in the understanding of contemporary educational inequality. In education policy, experimental research has found that voters are presently more concerned about and likely to hypothetically support policies that address income inequality in schooling than those that address racial inequality (Valant and Newark 2016). In the popular media, citing findings from and/or interviews with multiple scholars whose work on diverging outcome disparities by race and by income is reviewed below, a 2015 New York Times article summarized, "[R]acial disparities are still a stain on American society, but they are no longer the main divider. Today the biggest threat to the American dream is class" (Porter 2015).

To date, an important comparison has slipped through the cracks of the respective bodies of literature on outcome disparities by race and by parental income and conceptions of educational inequality based on them - namely, disparities between Black and White children whose parents have the same incomes. In this article, I track math test score disparities between Black and White students whose parents have similarly low, middle, or high incomes across three nationally representative data sources on ninth or tenth graders: Project TALENT (1960), High School and Beyond (1980) and the High School Longitudinal Study (2009). I also 
investigate the extent to which outcome disparities between same-income Black and White students are accounted for by racial differences, net of parental income, in family and school characteristics, such as, respectively, mother's education and school racial composition, and changes in these factors' explanatory power over time.

Throughout this article, I refer to differences in students' test scores by race, by parental income, and by race-within-income as "outcome disparities," as opposed to "achievement gaps." As multiple scholars have recently argued, the terminology of achievement gaps can, potentially, support deficit thinking and obscure the role, in producing unequal test scores, of historical and contemporary systemic inequalities in areas such as neighborhood and school quality, family resources, health, and political power (Chambers 2009; Flores 2007; Gutiérrez 2008; LadsonBillings 2006, 2007).

\section{BACKGROUND}

Theoretical Framework: An Intersectional Perspective on Race, Parental Income, and Fifty Years of Test Score Disparities

This study brings needed attention to race and income's historical intersectionality to research on trends in and explanations for disparities in children's test scores. On this question, an intersectional perspective rejects a race-versus-income dichotomy in favor of analyses of how the two have been and continue to be mutually constitutive (Collins 2000; Crenshaw 1989; Golash-Boza 2016; McCall 2005; for example applications in the education literature, see Irizarry 2015a, 2015b; López et al. 2018; Quadlin and Conwell 2020). As Clarke and McCall (2013: 350) write, intersectional theoretical arguments inhere the potential for "existing social facts previously viewed from a 'single-axis' lens...to be reinterpreted through a prism informed 
by multiple and at times conflicting social dynamics." Diverging trends of test score disparities by race and by parental income, therefore, offer a particularly ideal case for the application of an intersectional theoretical perspective.

Put in terms of methodological literature focused on quantitatively operationalizing critical theories (Stewart and Sewell 2011; Zuberi 2001; Zuberi and Bonilla-Silva 2008), this study's intersectional analytic framework is longitudinal and resourced-focused (see Stewart and Sewell 2011). I track outcome disparities across units of analysis formed by intersections of race and parental income over a fifty-year time period. As potential explanations for these disparities, I track race-parental income differences in family and school characteristics that have been of explanatory interest to the previously separate literatures on test score disparities by race and by parental income that this study integrates. I also estimate counterfactual outcome disparities under the assumption that there were not differences between Black and White children with same-income parents in these family and school factors at each time point.

\section{Families, Schools, and Test Score Disparities Between Black and White Students}

Today, the Black-White test score disparity remains statistically large and substantively consequential. According to 2012 data from the National Assessment of Education ProgressLong Term Trend Assessment (NAEP-LTT), the Black-White test score disparity among 13year-olds was .80 standard deviations (SDs) in math and .62 SDs in reading (Reardon et al. 2014). The large and multidisciplinary literature on the Black-White test score disparity features many studies that have often been able to explain sizeable portions of it by accounting for inequalities between Black and White children in characteristics of their schools and their families - with the latter including the parental SES measures of education, occupation, and 
income, in addition to or as proxy measures for other aspects of their family environments (e.g., Condron 2009; Fryer and Levitt 2004, 2006; Hanushek and Rivkin 2009; Phillips, Brooks-Gunn, et al. 1998; Phillips, Crouse, and Ralph 1998; Quinn 2015; Roscigno 1998, 2000; Yeung and Pfeiffer 2009).

Although today's Black-White test score disparity is a reminder of the persistence of racial inequality in children's life chances, its present size is the result of decades that have, on the whole, witnessed its closure. Black-White disparities in math and reading narrowed from the beginning of the 1970s through the end of the 1980s, widened during the 1990s, and have been narrowing since 1999, resulting in an overall decreasing trend (Magnuson and Waldfogel 2008; Reardon et al. 2014). The Black-White math and reading disparities among 13-year-olds reported above represent a 43 percent decrease in the reading disparity since 1971 and a 26 decrease in math disparity since 1978 (see Reardon et al. 2014).

Many studies have brought together nationally representative datasets, spanning this time period, to assess the extent to which over-time decreases in the Black-White test score disparity can be attributed to changes in Black-White inequality in family and school characteristics (Berends, Lucas, and Peñaloza 2008; Berends and Peñaloza 2008; Grissmer, Flangan, and Williamson 1998; Hedges and Nowell 1999, 1998). For example, Berends and colleagues (2008) did so with four datasets covering high school seniors in 1972, 1982, 1992, and 2004. In 1972, Black-White inequalities in family characteristics (mother's and father's education and occupational status) and school characteristics (proportion minority composition, mean socioeconomic composition, proportion in urban schools, proportion in private schools) both disadvantaged Blacks. Between 1972 and 2004, Black-White family SES inequalities decreased, while Black-White school inequalities increased. In other words, if Black-White inequalities in 
school characteristics would have remained stable or decreased over this time period, the BlackWhite test score disparity could have closed even more than was observed.

Families, Schools, and Test Score Disparities Between Students with High-Versus Low-Income Parents

Test score disparities between children of high- versus low-income parents have markedly increased over the same time period that the Black-White test score disparity has markedly decreased. Drawing on 12 datasets, Reardon (2011) demonstrated that, between cohorts of students born in 1940 and 2001, math and reading test score disparities between children whose parents were at the $90_{\text {th }}$ versus the $10_{\text {th }}$ percentile of the income distribution (i.e., the 90-10 income test score disparity) increased by 66 percent, from around .75 to 1.25 SDs. Income test score disparities have been driven by the rising correlation between family income and students' achievement, especially in the top half of the income distribution, not by income inequality per se (Reardon 2011). Parental education remains a stronger predictor of students' achievement than family income, but, over time, income has gained in explanatory power relative to parental education (Reardon 2011).

Inequalities in family and school characteristics are integral to candidate explanations for the income test score disparity, as is the case for the Black-White test score disparity. Inequalities in parental spending on children between high- versus low-income families have increased since the 1970s, and this spending has shifted towards the early childhood years, evidencing high-income parents' investments as preparation for K-12 schooling (Kornrich and Furstenberg 2013; Schneider, Hastings, and LaBriola 2018). Relatedly, income disparities in characteristics of children's family demographic contexts, such as their chances of having 
married parents, as well as developmental resources therein, such as children's books, remain large, although they have decreased slightly since 1998 (Bassok et al. 2016). During their K-12 years, high-income children are also more likely than their low-income peers to benefit from supplemental educational resources that parents provide, such as tutoring and test preparation (Buchmann, Condron, and Roscigno 2010).

High-income children have also experienced increased advantages in school context and composition relative to their lower-income peers. Income segregation between schools and districts increased between 1990 and 2010 (Owens, Reardon, and Jencks 2016). Income test score disparities are larger in metropolitan areas in which between-district income segregation is higher because high-income students perform better in those districts, consistent with a school district's income composition proxying for its level of financial and social resources (Owens 2018). High-income children have also had growing advantages in private school attendance since 1968 (Murnane and Reardon 2018), spelling increased disparities in access to the advantageous combination of school resources and culture, teachers, and peers that such schools provide (Figlio and Stone 2000).

To date, racial inequality has played a limited and specific role in the literature on income test score disparities. In order to answer the question, "how large are these [income achievement] gaps?" Reardon (2011, Figures 5.3 and 5.4), compared over-time changes in the size of the income test score disparities in math and reading to the size of the Black-White test score disparities in those subjects. For cohorts born in the 1940s to 1960s, the Black-White disparity was larger than the income disparity, but the opposite has been the case for cohorts born since the 1970s. The two disparities have continued to diverge for cohorts born since this crossover. 
Among the cohort born in 2000, today's college-aged youth, the 90-10 income test score disparity in math was more than twice the size of the Black-White disparity in that subject.

Families, Schools, and Test Score Disparities Between Black and White Children with SameIncome Parents

Cross-sectional findings of Black-White test score disparities between students from comparable parental income backgrounds provide the best evidence on the disparities that the present study investigates in longitudinal perspective. The little available evidence demonstrates the presence of such disparities and suggests that they vary in magnitude across the income distribution. Using data on adolescents and young adults aged 12 to 24 from the Adolescent Health Survey, Massey and Brodmann (2014) found that the Black-White disparity, to Blacks' disadvantage, in Peabody Picture Vocabulary Test (PPVT) ranged approximately 14 points in the bottom parental income quartile and a smaller to 11 points in the top parental income quartile.

There is also little systematic evidence of race-income inequalities in family and school characteristics and how they may have changed over time. Research on racial differences in family structure within education levels provides relevant, longitudinal background for family characteristics. Black mothers are less likely than same-education White mothers to be part of two-parent households (McLanahan and Percheski 2008). From 1960-2000, Black-White differences in single motherhood increased within the education levels of less than high school, high school, and college, and they have been largest among the least educated (McLanahan and Percheski 2008). Two-parent family structure is a facilitator of and proxy for numerous advantages for children (c.f., McLanahan and Percheski 2008). If the differences observed within education levels hold, to some extent, within income levels, it would mean that Black children 
are less likely than same-income White children to reap these benefits, and that these differences could be largest at lower income levels.

In the school domain, Black families are not as able as same-income White families to access socioeconomically advantaged school districts. In a recent cross-sectional study, Owens (2018) found that in the most economically segregated metropolitan areas, the median income of top-income-quintile White students’ school districts was over $\$ 60,000$, compared to just over $\$ 40,000$ for same-income Black students’ districts. Therefore, compared to same-income White students, Black students' achievement should not be expected to benefit equally from school and school district income composition, via the mechanisms of financial and social resources. Racial differences on this measure may be larger at higher parental income levels than at lower ones, since Black-White differences in school district median income are often larger among highincome families than among low-income families (Owens 2018).

\section{DATA AND METHODS}

\section{Data}

I observe student test score outcomes, family income, and family and school characteristics in either students' ninth or 10th grade year for students participating in three separate cohort-based longitudinal studies. Online Appendix A provides relevant information about question text, response categories, and coding for each variable that I use. All three studies on which I rely employed a multistage probability sampling design to generate samples of students that were representative of those enrolled in targeted grades in U.S. schools at the time the survey went into the field. For each survey, the analytic sample is Black and White students with non-missing information on the test outcome. In all three, I use the appropriate weight and 
adjust standard errors for the complex sampling design. I also use an extensive battery of established methods to aid with the datasets' reliability and comparability, as I detail below.

Data for the first time period come from the ninth graders from the base year of Project TALENT (American Institutes for Research 2013). The study was developed by the American Institutes for Research and funded by the United States Office of Education. In 1960, the national probability sample of students in over 1,000 junior and senior high schools included approximately 100,000 ninth graders. Students completed academic tests, as well as questionnaires about themselves and their families. School administrators also provided information about sampled schools. I use data on ninth graders so that patterns of interest are not conflated with large Black-White disparities in high school persistence and completion during this time period (e.g., U.S. Census Bureau 1999). For comparability, I use data on students of similar ages in the other two studies.

Data from the second time period come from tenth graders in the base year of High School and Beyond (HS\&B; United States Department of Education 2001), sponsored by the National Center for Education Statistics (NCES). In 1980, the national probability sample of students in over 1,000 high schools included approximately 25,000 10th graders. Students completed tests and provided information about themselves and their families. Parents, school administrators, and teachers also provided information.

Data from the third time period come from ninth graders in the High School Longitudinal Study (HSLS; Ingels et al. 2011), also sponsored by NCES. HSLS's base year data collection took place during the fall of the 2009-2010 school year. The study includes data from over 20,000 ninth graders in over 900 schools that offered both ninth and 11 th grades. Students completed tests and provided information about themselves and their families. Parents, school 
administrators, and teachers also provided information. Sample sizes for HSLS are rounded to the nearest 10, per NCES guidelines for restricted-use data.

\section{Variables}

Math test outcome. The outcome measure for this study is students' math test score - the only subject tested in all three surveys. In Project TALENT, I use students' combined scores for the three parts of the math assessment. The parts tested, respectively, arithmetic reasoning, introductory mathematics (e.g., Algebra), and advanced mathematics (e.g., geometry). In HS\&B, I use students' scores from part one of the math assessment.2 The assessment tested computation, arithmetic reasoning, graph reading, elementary algebra, and geometry (Jones et al. 1986). In HSLS, I use students' scores for the mathematics assessment in algebraic reasoning.

The three math assessments are theoretically comparable: all are tests of high school students' mathematics skills, tapping some of the same skill domains, such as Algebra. I make two additional adjustments to aid in the tests' comparability. First, I standardize each math test outcome to have a mean of zero and a SD of one by subtracting the unweighted national mean score from each student's score and dividing this result by the unweighted national standard deviation.3 I report test score disparities in SD units, tracking where students fall in the distribution of students who took the same test, instead of relying on the tests' differing score metrics. Second, I adjust all math test results for measurement error in the three math test instruments.4

2 This part of the HS\&B math assessment included the bulk of the items on the assessment (28 out of 38). Further, scores are available for a larger number of students on part one of the assessment than on part two.

3 For each survey, I conduct a single standardization for all students, meaning test scores are not standardized separately within income category or by race.

4 I use reliabilities of .75 for TALENT (Reardon 2011), .87 for HS\&B (Rock et al. 1985), and .92 for HSLS (Ingels et al. 2011). 
Parental income. The key explanatory variable for this study is parental income. In Project TALENT, students reported their family income from 1959, from parents and anyone else in the household who worked, in five categories. In HS\&B, students reported their families' incomes in seven categories. In HSLS, parents reported family income from 2008 in 13 categories. Online Appendix A provides the dollar values corresponding to the income categories in each dataset. As detailed below, I adapt methods developed by Reardon (2011) to convert these categories to weighted income percentiles that are comparable across the datasets. Along with adjusting math test score disparities for measurement error in the math test instrument, I also adjust them for measurement error in the income reports, based on whether income was reported by parents or students, and, if by students, differentially based on the students' age. 5

Previous research has shown that Black-White test score disparities conditional on current parental income may be upwardly biased, compared to estimates conditional on permanent parental income (Rothstein and Wozny 2013). Multiple features of this study's analytic strategy are likely to substantially reduce the amount of this bias, although I cannot claim that it is completely eliminated. Primarily, the high school students in this study's analytic sample are old enough that, on average, their parents are at an age where their current income is a reasonable proxy for their permanent income (early thrities to mid-forties; see Haider and Solon 2006; Rothstein and Wozny 2013, Figure A1).

Other explanatory variables: race and family and school characteristics. In analyses of all three surveys, I also draw on variables for race and family and school characteristics. I code students as Black or White, based on their response to the relevant question in each survey. For

5 Following Reardon (Reardon 2011), I use income reliabilities of .50 for the 9 th grader-reported income in TALENT, .57 for the 10th grader-reported income in HS\&B, and .86 for the parent-reported income in HSLS. I do not adjust estimates of family and school characteristics for measurement error in parental income. 
family characteristics, I include variables for mother's education (in years), whether or not the student lives in a two-parent household, and family size. Students report these characteristics in TALENT and HS\&B, and parents report them in HSLS (see Online Appendix Tables A1-A3). 6 For school characteristics, I include variables for the percentage of economically disadvantaged students in the school, the percentage of Black students in the school, and the percentage of White students in the school. In all three surveys, school administrators reported this information (see Online Appendix Tables A1-A3). I also created a variable for the average math test score of sampled students in the school, in order to measure the school's academic context in a way that could be done consistently across the three surveys.

Multiple imputation. Within each survey, some students with non-missing information on the math test outcome were missing data on explanatory variables, including income (in TALENT and HS\&B). I imputed missing data with the ice commands in Stata 14.1, using multivariate imputation using chained equations (MICE) with 5 iterations (Royston 2005). For each survey, the imputation model included students' school identifier, their race and parental income percentile, all other explanatory variables discussed above, and was weighted by the appropriate sampling weight. It also included the math test outcome variable in order to preserve its relationships with the explanatory variables; for each survey, results presented below are based only on the subset of students who had a non-missing score for that outcome in the

\footnotetext{
6 Previous research in the sociology of education literature has shown that students' reports of variables such as parental education can suffer from some of the same issues that their reports of parental income do (John 1970; Kerckhoff, Mason, and Poss 1973; Looker 1989). I do not adjust estimates of family characteristics for this potential bias, since previous studies have come to varying conclusions about the direction of its magnitude. This should be kept in mind when considering estimates involving family characteristics in TALENT and HS\&B, the two datasets where family characteristics are reported by students, not parents. I also do not adjust estimates of family and school characteristics for measurement error in income. Applying the correction used to adjust math gaps (multiplying estimates by a scaling factor based on the reliability) results in implausible estimates, given existing knowledge about the distribution of characteristics like maternal education.
} 
original data (von Hippel 2007). I also imputed race for some students in Project TALENT during this procedure (for details, see Online Appendix B).

\section{ANALYTIC STRATEGY}

\section{Statistical Model}

Previous studies on test score disparities and family and school resource inequalities between children of high- versus low-income parents (Bassok et al. 2016; Reardon and Portilla 2016) have relied on the cubic regression method originally developed by Reardon (2011). By regressing a variable for a test score outcome or a given family or school characteristic (e.g., mother's education) on variables for income percentile, income percentile squared, and income percentile cubed, one can predict values of the variable at specified income percentiles, as well as differences in values between income percentiles (e.g., $90_{\text {th }}$ vs. $10_{\text {th }}$ percentile inequality). Here, I adapt this method to assess Black-White test score disparities and family and school resource inequalities between children whose parents are at the same income percentile. To do so, I interact an indicator variable for race $($ Black $=1$, White $=0)$ with the three income terms in the cubic regression specification. The main analytic model is shown in Equation 1, below:

$$
\begin{aligned}
& \text { Outcome }_{i t}=\beta_{0 t}+\beta_{1 t}\left(\text { Black }_{i t}\right)+\beta_{2 t}\left(\text { IncPct }_{i t}\right)+\beta_{3 t}\left(\text { IncPct }_{i t}^{2}\right)+\beta_{4 t}\left(\text { IncPct }_{i t}^{3}\right)+ \\
& \beta_{5 t}\left(\text { Black }_{i t} * \text { IncPct }_{i t}\right)+\beta_{6 t}\left(\text { Black }_{i t} * \text { IncPct }_{i t}^{2}\right)+\beta_{7 t}\left(\text { Black }_{i t} * \text { IncPct }_{i t}^{3}\right)+\varepsilon_{i t}
\end{aligned}
$$

where, for each timepoint $t\left(1960,1980\right.$, or 2009), Outcome $_{i}$ is the standardized math score or a given family or school characteristic for student $i ; \beta_{0}$ is an intercept term; $\beta_{1}$ is a main effect for race; $\beta_{2-4}$ are main effects for income percentile, income percentile squared, and income 
percentile cubed; $\beta_{5-7}$ are interactions of race with these income terms; and $\varepsilon_{i}$ is an error term. I estimate all disparities net of students' gender and age, both of which are also interacted with all three income terms. Results focus on the 10th, 50th, and 90th percentiles, following previous research on test score and resource disparities by parental income.

Online Appendix C shows the results of converting the three survey's categorical income variables to weighted income percentiles for use in the cubic regression procedure. At all three time points, Blacks are overrepresented in lower income percentiles and underrepresented at higher income percentiles. Comparisons at the $10_{\mathrm{th}}, 50 \mathrm{th}$, and $90_{\mathrm{th}}$ income percentiles based on the pooled (White and Black) distribution always correspond to higher percentiles in Blacks' own-race income distribution. Often, the 10th percentile is near the median of Blacks' distribution, the 50 th percentile is well into the right tail, and the 90 th percentile indexes a small number of economically elite Blacks. Readers should keep this in mind when interpreting the results below, as all results are predictions based on percentiles of the pooled income distribution. Robust standard errors for these predictions have the desirable property of varying in magnitude to reflect uncertainty based on differential coverage at various points in the income distribution; for example, they are larger for predictions for higher income Blacks, reflecting sparser coverage in the right tail of the income distribution.

\section{Plan of Analyses}

Below, I first use the model given in Equation 1 to predict Black-White disparities in math achievement and family and school characteristics at specified income percentiles. I then assess the extent to which the latter account for the former. I do this by re-estimating students' math scores, this time net of controls for 1) family factors, 2) school factors, and 3) both. I 
interact all of these variables with the three terms in the cubic income specification, allowing their effects to vary by income. I then re-predict Black-White disparities at the focal income levels as if Blacks had the same means on family and school factors as same-income Whites. The models also implicitly assume that these factors' effects on achievement are equal across races. These counterfactual analyses are descriptive and correlational, and as such should not be given a causal interpretation.

\section{RESULTS}

Black-White Math Test Score Disparities Between Students with Same-Income Parents, 19602009

Table 1, below, presents estimates of Black-White test score disparities between students with parents at the $10_{\mathrm{th}}, 50 \mathrm{th}$, and $90 \mathrm{th}$ percentiles of the income distribution in 1960, 1980, and 2009. Figure 1, also below, provides additional context for these estimates by presenting test score predictions for Black and White students at each income decile at all three time points. Figure 1 reminds that, over this fifty-year time period, changes in within-race test score stratification by parental income have been behind Black-White test score disparities between students with same-income parents. From 1960-2009, this measure has increased within both racial groups. For Blacks, it has done so while the whole group has improved its average position in the national achievement distribution, consistent with the shrinking average Black-White test score disparity. Among Whites, children from high-income families have more or less maintained their position at the top of the achievement distribution, while, over time, lowerincome Whites have fallen back. 
Table 1. Black-White Math Test Score Disparities, by Year and Parental Income Percentile

\begin{tabular}{|c|c|c|c|c|c|c|c|}
\hline $\begin{array}{l}\text { Parental Income } \\
\text { Percentile }\end{array}$ & & 1960 & & 1980 & & 2009 & 1960-2009 \\
\hline & $B$ & S.E. & $B$ & S.E. & $B$ & S.E. & $B \quad$ S.E. \\
\hline 10th & -1.47 & $(.05) * * *$ & -.89 & $(.04) * * *$ & -.39 & $(.07) * * *$ & $1.07(.09) * * *$ \\
\hline 50th & -1.50 & $(.06) * * *$ & -1.16 & $(.05) * * *$ & -.49 & $(.08) * * *$ & $1.01(.10) * * *$ \\
\hline 90th & -1.64 & $(.16) * * *$ & -1.43 & $(.12) * * *$ & -.58 & $(.14) * * *$ & $1.06(.22) * * *$ \\
\hline$N$ & & 9,019 & & 4,551 & & 10,970 & 134,540 \\
\hline
\end{tabular}

Notes: Robust standard errors in parentheses. Notes: Numbers of observations for 2009 (High School Longitudinal Study) rounded to nearest 10, per National Center for Education Statistics guidelines.

$* * * p<.001 ; * * p<.01 ; * p<.05$ 

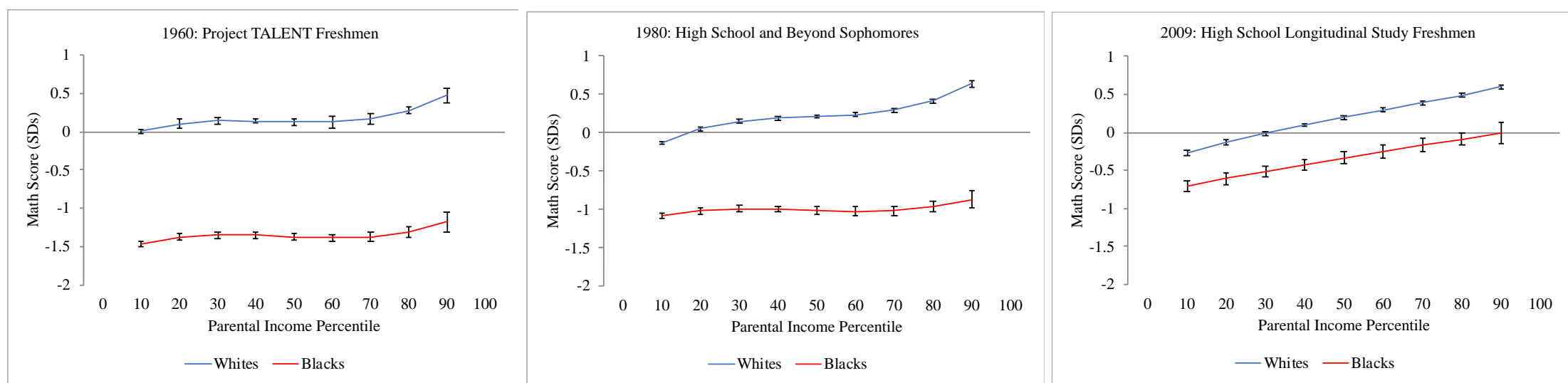

Figure 1. Math Test Score (Standard Deviations), by Year, Parental Income Percentile, and Race

Notes: Error bars represent robust standard errors. 
1960. In 1960, the test score disparity between Black and White children with sameincome parents was $-1.47 \mathrm{SDs}$ at the 10 th parental income percentile, $-1.50 \mathrm{SDs}$ at the $50 \mathrm{th}$ income percentile, and -1.64 SDs at the 90th income percentile $(p<.001$ for all such disparities at all percentiles). These three disparities were not significantly different from each other.

1980. These disparities all decreased between 1960 and 1980. Deceases were largest at the 10th income percentile, where the disparity fell to -.89 SDs, and successively smaller at the 50th and 90th income percentiles, where remaining disparities were -1.16 SDs and -1.43 SDs, respectively. These patterns resulted in Black-White math test score disparities at the 50th and 90 th income percentiles being significantly larger than the one at the 10 th percentile $(p<.001$ for both comparisons), which was not the case in 1960 . The disparity at the 90 th percentile was also significantly larger than the one at the 50th percentile $(p<.05)$, also not the case in 1960 . Therefore, in 1980, Black children whose parents had incomes at the national median, making them relatively well-off for their racial group, were farther behind same-income Whites than low-income Black children were relative to their same-income White peers. Although predictions for the most economically elite Blacks are measured with less precision due to their small numbers, they indicate that these children were even farther behind their same-income White peers.

2009. Disparities at all three focal income levels continued to decrease between 1980 and 2009. In contrast to the changes between 1960 and 1980, however, between 1980 and 2009, decreases in disparities were larger at higher income levels (.50 SDs at the 10th percentile, .67 SDs at the 50th percentile, and .84 SDs at the 90 th percentile). These patterns closed the significant differences between these disparities at the three percentiles observed in 1980, returning them to being statistically indistinguishable from each other, as observed in 1960 . 
Table 1's rightmost panel shows that, between 1960 and 2009, math test score disparities between Black and White children with same-income parents decreased by a comparable amount of between one and one and one-tenth of an SD. Despite patterns of within-race test score differentiation by parental income that have come to look more like those among Whites over the 50-year period, at any given income level, Blacks still faced a consistent math test score disparity relative to their same-income White counterparts in 2009, ranging between -.39 SDs at the $10_{\text {th }}$ income percentile to $-.58 \mathrm{SDs}$ at the 90 th income percentile.

Black-White Differences in Family and School Characteristics Between Students with SameIncome Parents, 1960-2009

Table 2, below, shows Blacks' and Whites' means on family and school characteristics at the $10_{\mathrm{th}}, 50 \mathrm{th}$, and $90 \mathrm{th}$ parental income percentiles in 1960, 1980, and 2009. Taken together, these descriptive results indicate that, at a given income level, Black children have often not had the same access as Whites to the family and school factors that previous research has found to be partially responsible for decreasing Black-White test score disparities and increasing income test score disparities. 
Table 2. Means of Family and School Characteristics, by Year and Parental Income Percentile

\begin{tabular}{|c|c|c|c|c|c|c|c|c|c|}
\hline \multirow[b]{2}{*}{ Parental Income Percentile and Variable } & \multicolumn{3}{|c|}{1960} & \multicolumn{3}{|c|}{1980} & \multicolumn{3}{|c|}{2009} \\
\hline & White & Black & & White & Black & & White & Black & \\
\hline \multicolumn{10}{|l|}{ 10th Income Percentile } \\
\hline Mother's Education (Years) & 11.27 & 10.76 & $* * *$ & 11.70 & 11.56 & & 12.42 & 12.56 & \\
\hline Two-Parent Household & .84 & .60 & $* * *$ & .77 & .55 & $* * *$ & .56 & .38 & $* * *$ \\
\hline Family Size & 4.03 & 5.40 & $* * *$ & 3.04 & 4.25 & $* * *$ & 2.17 & 2.32 & \\
\hline Percentage of Economically Disadvantaged Students in School (Original Metric) a & 11.20 & 27.19 & $* * *$ & 14.06 & 36.26 & $* * *$ & 40.74 & 58.76 & $* * *$ \\
\hline B/W Ratio of Economically Disadvantaged Students in School & & 2.43 & & & 2.58 & & & 1.44 & \\
\hline Percentage of Black Students in School & 3.57 & 86.31 & $* * *$ & 7.71 & 53.65 & $* * *$ & 10.73 & 45.56 & $* * *$ \\
\hline Percentage of White Students in School & 88.64 & 9.72 & $* * *$ & 85.80 & 39.95 & $* * *$ & 76.68 & 34.59 & $* * *$ \\
\hline Average Math Achievement Score of Sampled Students in School (SDs) & .03 & -.89 & $* * *$ & -.01 & -.50 & $* * *$ & -.15 & -.34 & $* * *$ \\
\hline \multicolumn{10}{|l|}{ 50th Income Percentile } \\
\hline Mother's Education (Years) & 11.74 & 11.39 & ** & 12.35 & 12.12 & & 13.81 & 14.08 & \\
\hline Two-Parent Household & .85 & .61 & $* * *$ & .88 & .62 & $* * *$ & .89 & .73 & $* * *$ \\
\hline Family Size & 3.92 & 5.31 & **** & 2.77 & 3.95 & $* * *$ & 2.17 & 2.30 & \\
\hline Percentage of Economically Disadvantaged Students in School (Original Metric) a & 10.41 & 25.65 & $* * *$ & 11.70 & 30.31 & $* * *$ & 30.78 & 46.28 & * \\
\hline B/W Ratio of Economically Disadvantaged Students in School & & 2.46 & & & 2.59 & & & 1.50 & \\
\hline Percentage of Black Students in School & 3.70 & 86.83 & **** & 7.26 & 50.07 & $* * *$ & 10.23 & 34.61 & $* * *$ \\
\hline Percentage of White Students in School & 88.63 & 9.41 & $* * *$ & 87.23 & 43.54 & $* * *$ & 76.00 & 41.16 & $* * *$ \\
\hline Average Math Achievement Score of Sampled Students in School (SDs) & .06 & -.86 & $* * *$ & .07 & -.44 & $* * *$ & .00 & -.18 & $* *$ \\
\hline \multicolumn{10}{|l|}{ 90th Income Percentile } \\
\hline Mother's Education (Years) & 13.00 & 12.71 & & 13.81 & 13.78 & & 15.63 & 16.21 & \\
\hline Two-Parent Household & .93 & .66 & $* * *$ & .96 & .81 & ** & .96 & .99 & \\
\hline Family Size & 3.65 & 5.14 & $* * *$ & 2.62 & 4.29 & $* *$ & 2.16 & 2.21 & \\
\hline Percentage of Economically Disadvantaged Students in School (Original Metric) a & 6.18 & 21.42 & $* * *$ & 7.83 & 27.65 & $* * *$ & 19.20 & 32.81 & \\
\hline B/W Ratio of Economically Disadvantaged Students in School & & 3.47 & & & 3.53 & & & 1.71 & \\
\hline Percentage of Black Students in School & 3.04 & 87.30 & $* * *$ & 6.30 & 47.93 & $* * *$ & 8.89 & 30.36 & * \\
\hline Percentage of White Students in School & 89.33 & 8.68 & $* * *$ & 88.46 & 44.48 & $* * *$ & 72.68 & 48.46 & $* * *$ \\
\hline Average Math Achievement Score of Sampled Students in School (SDs) & .20 & -.77 & $* * *$ & .26 & -.28 & $* * *$ & .28 & .10 & $*$ \\
\hline$N$ & 91,579 & 7,440 & & 20,876 & 3,675 & & 9,390 & 1,580 & \\
\hline
\end{tabular}


Family characteristics. I use three variables to measure Black-White differences in family characteristics between same-income students: maternal education, two-parent family structure, and family size. In 1960, at all income levels, Black students' mothers had completed less schooling than White students' mothers (significantly so at the 10th and 50th income percentiles). By 1980, Black-White differences at the 10th and 50th percentiles were no longer significant, and by 2009, Blacks' point estimates were higher than Whites' at each income level.

In 1960, Blacks at all income levels were significantly less likely to grow up in twoparent households than same-income Whites, with differences ranging from 24 percentage points at the 10 th income percentile to 27 percentage points at the 90 th percentile. Between 1960 and 2009, 10th-income-percentile households of both races experienced decreases on this measure, 50th and 90th percentile Whites' rates stayed relatively flat, and 50th and 90th percentile Blacks' rates increased. As a result, by 2009, Black-White differences in likelihood of living in a twoparent household were much larger at the 10 th income percentile (.56 for Whites vs. .38 for Blacks, $p<.001)$ than at the 50th $(.89$ for Whites vs. .73 for Blacks, $p<.001)$ and 90 th percentiles (.96 for Whites vs. .99 for Blacks, NS).

Over this time period, Blacks and Whites of all income levels experienced large decreases in average family size. These decreases were larger for Blacks, resulting in relative parity of family size by 2009 , at an average of slightly more than two children for all raceincome groups. Trends on this measure signal decreasing racial disparities over time in exposure to the possibility family resources will be spread across larger numbers of children.

School characteristics. I measure school context and composition with variables for school economic and racial composition, as well as a variable for the average math achievement score of sampled students in the school. Predictably, at all three time points, Black students 
attended schools with significantly higher percentages of Black students than same-income Whites. These differences decreased over time, as White students' schools enrolled slightly larger shares of Black students, and Black students' schools enrolled much smaller shares of them. For example, among children of median-income parents, in 1960, Black students attended schools where, on average, 86.83 percent of their classmates were Black, compared to a figure of approximately 3.70 percent for White students ( $p<.001$ for difference). By 2009, the same figures were 34.61 and 10.23 percent, respectively ( $p<.001$ for difference).

Table 2 also provides information on the percentage of White classmates in students' schools. White children's percentages of White classmates have decreased slightly over time (between 12 and 15 percentage points, depending on the income level). Black children's percentages of White classmates have increased, particularly from 1960 to 1980, where at each income level, Blacks' figure increased by over 30 percentage points. Between 1980 and 2009, 10th and 50th income percentile Black children's shares of Black and White classmates both decreased, signaling increased shares of Latinx and other non-White students. Ninetieth income percentile Black children's share of Black classmates also fell (from $47.93 \%$ in 1980 to 30.36 percent in 2009), but their share of White classmates continued to increase (44.48\% in 1980 to 48.46 in 2009).

The metric for percentage of economically disadvantaged students in schools varied across the surveys (see Online Appendix Tables A1-A3). In Table 2, I present this characteristic in the original metric as well as in ratio terms, to facilitate comparisons over time. At each income level and time point, Black students were predicted to attend schools with significantly higher percentages of economically disadvantaged students than the schools that same-income White students attended. Between 1960 and 2009, these differences got smaller at all income 
levels. In 1960, 10th-income-percentile Black students' schools enrolled 2.43 times the percentage of economically disadvantaged students that same-income White students' schools did, and this disparity shrunk to 1.44 times by 2009 . Trends were similar at the 50 th income percentile. At the 90th income percentile, predictions for the most economically elite Blacks show that Black students' schools enrolled 3.47 times the percentage of economically disadvantaged students that same-income White students' schools did, and that this disparity shrunk to only 1.71 times by 2009.

The variable for the average math test score of sampled students in the school reveals that, at each income level and time point, Black students have attended schools that fare significantly worse on this measure than same-income Whites. In 1960, the average math test score in Black students' schools was approximately one SD below that of same-income White students' schools. At this time, the average math test score in the most economically elite Black students' schools (-.77 SDs for Blacks at the 90th income percentile) was approximately threequarters of an SD below that of the least economically advantaged White students' schools (.03 SDs at the 10th income percentile). This school-level disparity has also decreased over time, although it remains significant at each income level.

\section{Accounting for Black-White Math Test score disparities Between Students with Same-Income} Parents, 1960-2009

Figure 2, below, shows the results of a counterfactual exercise that re-predicts BlackWhite test score disparities between children with same-income parents as if Blacks had the same a) family, b) school, and c) family and school characteristics as same-income Whites and these factors' effects on math test scores were equal across races. Online Appendix D shows the linear regression coefficients used for the calculations. To reiterate, these counterfactuals are 
descriptive and correlational, and as such should not be given a causal interpretation. Also, recall from Figure 1 that math test score disparities between Black and White students with sameincome parents are appreciably smaller in 2009 than in earlier years. This fact may be substantively important, a point to which I return below. 


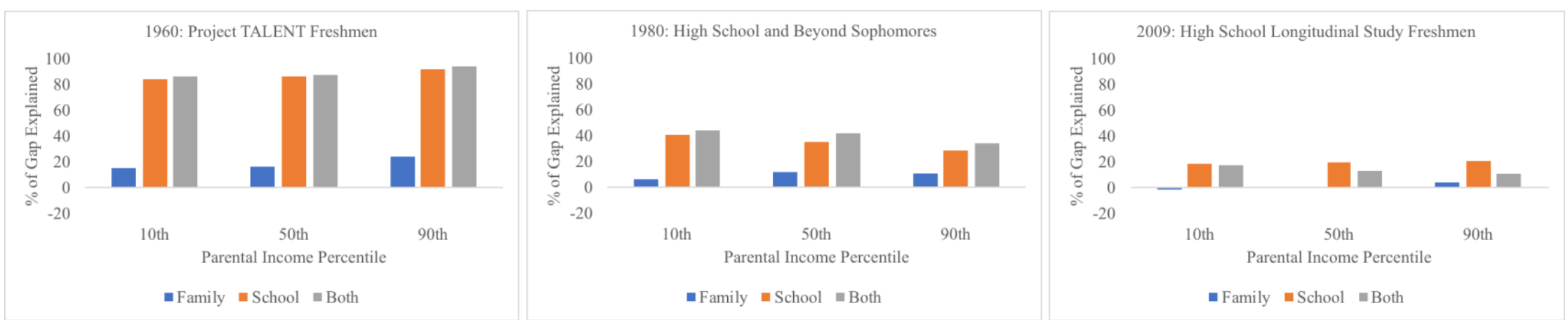

Figure 2. Percentage of Black-White Math Test Score Disparities Between Same-Income Students Explained by Regression Adjustment Procedure, by Year and Parental Income Percentile 
Over time, these family and school factors account for markedly declining shares of Black-White test score disparities between students with same-income parents. In 1960, the counterfactual exercise accounts for at least 80 percent of the disparities across income percentiles - driven by school factors' explanatory power - with the largest percentage explained (95 percent) at the 90th income percentile. By 1980, these same factors account for 44 percent of the disparity at the $10_{\text {th }}$ income percentile, 42 percent at the 50th income percentile, and 35 percent at the 90th percentile, evidencing declines in explanatory power and a reversal of the pattern observed in 1960, when the factors accounted for a larger percentage of the disparity at the highest income level. This trend continues from 1980 to 2009, when these family and school characteristics account for less than 18 percent of the math test score disparity between sameincome Black and White children at the 10th income percentile, 14 percent at the 50th income percentile, and 11 percent at the $90_{\text {th }}$ income percentile.

The year 2009 is also the first time point when adjusting for family characteristics in addition to school characteristics results in larger disadvantages for Blacks (i.e., the percentage of disparity explained decreases from the family to the family-plus-school models in Figure 2). By this time period, adjusting for family characteristics controls away Blacks' advantages relative to same-income Whites on factors that are positively correlated with achievement, such as maternal education (see Table 2 and Online Appendix D). In sum, although Black-White math test score disparities between high schoolers with same-income parents have decreased substantially since 1960, differences between such students in many family and school characteristics known to facilitate achievement have also decreased. These factors' ability to account for the disparities has also considerably decreased, leaving large percentages of them to be explained in 2009 . 
What are we to make of the simultaneous decline in both within-income math test score disparities and the potential contribution of family and school factors to those disparities? At least two interpretations are worth noting. On one hand, at least within income levels, Black and White students' family and school environments, as measured by these variables, have in many cases provided more equitable opportunities for academic success than they have in the past. This makes them less likely to contribute appreciably to continued reductions in outcome disparities, even if the outcome disparities continue to decrease over time. On the other, these particular outcome disparities may be stubborn to change, as the legacy of discrimination and structural racism, present at all periods, may make it such that further reductions in these disparities will only come about when racial inequality is reduced in factors spanning well beyond a single generation of students' family and school environments.

\section{DISCUSSION AND CONCLUSION}

In this study, I have documented Black-White math test score disparities between ninth or tenth graders whose parents have the same incomes, across three nationally representative data sources spanning 1960-2009. Doing so has served to integrate the literatures concerning diverging trends of test score disparities, since the mid-twentieth century, by race - which have been decreasing - and by income - which have been increasing. These diverging trends presented an ideal case for the application of an intersectional theoretical framework. The study joins a number of recent works in the education literature that have applied an intersectional viewpoint (Irizarry 2015a, 2015b; López et al. 2018; Quadlin and Conwell 2020). It has contributed to this growing research stream by analyzing intersectional - in this case, race $\mathrm{x}$ income - educational inequalities in historical perspective. 
There are three main findings. First, Black-White test score disparities between children with same income parents are to Blacks' disadvantage and decreased over this time period, by about one SD at each of this study's three focal income levels. Despite this closure, in 2009, remaining disparities were substantively large, statistically significant, and largest at higher income levels. Second, Black-White differences, net of income, in family and school factors that scholars commonly use to explain test score disparities have often decreased over time, but some remain large and significant, measures of school racial and socioeconomic composition. Third, due in part to these decreases, family and school factors have accounted for markedly decreasing shares of shrinking test score disparities between same-income students over time.

Future research should investigate what other mechanisms are responsible for test score disparities and resource differences between same-income Black and White students. Although data on wealth were not available in the datasets that I used for this study, Black-White differences in wealth, net of income (e.g., Darity Jr. et al. 2018) are one possible explanation. Wealth has direct effects on children's educational outcomes, net of income (Orr 2003; Pfeffer 2018). Parents can also leverage wealth to facilitate developmentally advantageous environments for their children in ways that same-income families with less wealth, net of income, cannot, potentially leading to indirect effects of wealth on children's school experiences and outcomes. For example, families may utilize a wealth transfer to garner access to homes in neighborhoods with more economically advantaged school districts that are, on average, better able to boost children's intellectual growth. This proposed mechanism is consistent with observed BlackWhite differences between-same income families in neighborhood (e.g., Sharkey 2014) and school district (Owens 2018) economic composition. Along with being conduits of wealth effects (see Pfeffer 2018), neighborhoods themselves may also help produce Black-White differences 
between same-income students and families, since neighborhood disadvantage influences children's cognitive development (e.g., Sharkey and Elwert 2011).

Recently, sociologists have illustrated how race is embedded in the functioning of organizations, including schools (Diamond 2018; Ray 2019). Consistent with this, future research should also consider the role of within-school inequalities in producing Black-White test score disparities between same-income students. In racially integrated schools, Black students and families may be exposed to, and White students and families may benefit from, multiple forms of discriminatory treatment and opportunity hoarding, including, but not limited to, racialized tracking and negative teacher and school administrator reactions to Black parents' attempts to become involved in their children's schooling (Ispa-Landa and Conwell 2015; Lareau and Horvat 1999; Lewis-McCoy 2014; Lewis and Diamond 2015; Tyson 2011). While they may have effects across the income distribution, these factors may also play a more substantial role in Black-White test score disparities among higher income students, which, as demonstrated above, are larger than those among lower income students. This is because, as also demonstrated above, higher income Black students are more likely than their low- and middle-income counterparts to attend schools that are racially integrated, an arrangement that can, potentially, motivate Whites to use racialized school organizational systems to maintain advantages (Lewis and Diamond 2015; Tyson 2011).

Previous research indicates that opportunities to learn, such as coursetaking, are particularly important to the hierarchical curricular structure of math learning (e.g., Kelly 2009), meaning these patterns may be particularly relevant to disparities on the outcome considered here. Data limitations prevented a systematic analysis of this possibility across the three datasets this study used - primarily the fact that the datasets did not measure students' math coursetaking 
in a consistent fashion over time. However, supplemental analyses for the most recent dataset, the HSLS, using a retrospective survey question on ninth graders' eighth grade math coursetaking (see Online Appendix E) indicated race-income differences, to Blacks' disadvantage and to Whites' advantage, in this type of opportunity to learn - measured, for example, as exposure to Algebra I prior to high school entry. Future research should seek to link racially unequal coursetaking patterns and other forms of opportunity hoarding to outcome disparities at the intersection of race and income.

This study's findings and their implications should be considered in light of at least two limitations. First, results have been confined to math achievement, the only subject tested in all three datasets used here. While math achievement has implications for students' success in STEM education and related domains (e.g., Riegle-Crumb and King 2010), patterns of raceincome inequality in children's test score outcomes may differ in reading, where average BlackWhite test score disparities are smaller. Second, this study has also only used data on ninth or tenth graders. Both Black-White and income test score disparities are large by the time children begin formal schooling in the fall of kindergarten, and, as children age, the Black-White disparity continues to grow, while the income test score disparity remains stable (Reardon 2011; Reardon et al. 2014). Therefore, the repeated historical cross-sections presented above may miss noteworthy changes in Black-White disparities between same-income students as they age.

As noted in this study's Introduction, recent discussions of test score disparities have given primacy to those between the children of high- versus low-income parents, due to their increasing trend. Moreover, this increase has occurred while income returns to educational attainment and cognitive skills have also increased (e.g., Lemieux 2006). Currently, "the children of the rich do better in school, and those who do better in school are more likely to become rich" 
(Reardon 2011: 111). Findings presented here demonstrate that, over this same time period, race's influence on children's math test scores has been and continues to be structural in nature that is, over and above the constellation of factors believed to govern the distribution of the outcome (see Duncan 1967 for a classical discussion), including factors, like income, that have, over time, become much stronger correlates of children's test scores. These patterns should be borne in mind by future theory, research, and policy concerning disparities in children's test score outcomes and schooling's role in the intergenerational transmission of economic (dis)advantage. 


\section{REFERENCES}

American Institutes for Research. 2013. Project Talent, Base Year Data [Computer File] (ICPSR33341-V2). Ann Arbor, MI: Inter-university Consortium for Political and Social Research [Distributor].

Bassok, Daphna, Jenna E. Finch, RaeHyuck Lee, Sean F. Reardon, and Jane Waldfogel. 2016. "Socioeconomic Gaps in Early Childhood Experiences." AERA Open 2(3):1-22.

Berends, Mark, Samuel R. Lucas, and Roberto V. Peñaloza. 2008. "How Changes in Families and Schools Are Related to Trends in Black-White Test Scores." Sociology of Education 81(4):313-44.

Berends, Mark and Roberto V. Peñaloza. 2008. "Changes in Families, Schools, and the Test Score Gap." Pp. 66-109 in Steady Gains and Stalled Progress: Inequality and the BlackWhite Test Score Gap, edited by K. Magnuson and J. Waldfogel. Russell Sage Foundation.

Buchmann, Claudia, Dennis J. Condron, and Vincent J. Roscigno. 2010. "Shadow Education, American Style: Test Preparation, the SAT and College Enrollment." Social Forces 89(2):436-62.

Chambers, Terah Venzant. 2009. “The 'Receivement Gap': School Tracking Policies and the Fallacy of the "Achievement Gap."” The Journal of Negro Education 78(4):417-31. Retrieved (https://www.jstor.org/stable/25676096).

Clarke, Averil Y. and Leslie McCall. 2013. "Intersectionality and Social Explanation in Social Science Research.” Du Bois Review 10(2):349-63.

Coleman, James S. et al. 1966. Equality of Educational Opportunity. Washington, D.C.: U.S. Government Printing Office.

Collins, Patricia Hill. 2000. Black Feminist Thought: Knowledge, Consciousness, and the Politics of Empowerment. New York: Routledge.

Condron, Dennis J. 2009. "Social Class, School and Non-School Environments, and Black/White Inequalities in Children's Learning.” American Sociological Review 74(5):685-708.

Crenshaw, Kimberle. 1989. "Demarginalizing the Intersection of Race and Sex: A Black Feminist Critique of Antidiscrimination Doctrine, Feminist Theory, and Antiracist Politics." The University of Chicago Legal Forum (1):139-67.

Darity Jr., William et al. 2018. What We Get Wrong About Closing the Racial Wealth Gap. Durham, NC and Oakland, CA. Retrieved (https://socialequity.duke.edu/sites/socialequity.duke.edu/files/site-images/FINAL COMPLETE REPORT_.pdf). 
Diamond, John B. 2018. "Race and White Supremacy in the Sociology of Education: Shifting the Intellectual Gaze.” Pp. 345-62 in Education in a New Society: Renewing the Sociology of Education, edited by J. Mehta and S. Davies. Chicago, IL: University of Chicago Press.

Duncan, Otis Dudley. 1967. "Discrimination against Negroes." The ANNALS of the American Academy of Political and Social Science 371(1):85-103.

Figlio, David N. and Joe A. Stone. 2000. “Are Private Schools Really Better?” Research in Labor Economics 18:115-40.

Flores, Alfinio. 2007. "Examining Disparities in Mathematics Education: Achievement Gap or Opportunity Gap?” The High School Journal 91(1):29-42.

Fryer, Roland G. and Steven D. Levitt. 2006. "The Black-White Test Score Gap Through Third Grade." American Law and Economics Review 8(2):249-81.

Fryer, Roland G. and Steven D. Levitt. 2004. "Understanding the Black-White Test Score Gap in the First Two Years of School." The Review of Economics and Statitsics 86(2):447-64.

Golash-Boza, Tanya. 2016. "A Critical and Comprehensive Sociological Theory of Race and Racism." Sociology of Race and Ethnicity 2(2):129-41.

Grissmer, David, Ann Flangan, and Stephanie Williamson. 1998. "Why Did the Black-White Test Score Gap Narrow in the 1970s and 1980s?” Pp. 182-226 in The Black-White Test Score Gap, edited by C. Jencks and M. Phillips. Washington, D.C.: Brookings Institution Press.

Gutiérrez, Rochelle. 2008. “A 'Gap-Gazing’ Fetish in Mathematics Education? Problematizing Research on the Achievement Gap." Journal for Research in Mathematics Education 39(4):357-64. Retrieved (https://www.jstor.org/stable/40539302).

Haider, Steven and Gary Solon. 2006. "Life-Cycle Variation in the Association between Current and Lifetime Earnings." American Economic Review 96(4):1308-20.

Hanushek, Eric A. and Steven G. Rivkin. 2009. "Harming the Best: How Schools Affect the Black-White Achievement Gap." Journal of Policy Analysis and Management 28(3):36693.

Hedges, Larry V. and Amy Nowell. 1998. "Black-White Test Score Convergence since 1965." Pp. 149-81 in The Black-White Test Score Gap, edited by C. Jencks and M. Phillips. Washington, D.C.: Brookings Institution Press.

Hedges, Larry V. and Amy Nowell. 1999. "Changes in the Black-White Gap in Achievement Test Scores." Sociology of Education 72(2):111-35.

von Hippel, Paul T. 2007. "Regression with Missing Ys: An Improved Strategy for Analyzing 
Multiply Imputed Data." Sociological Methodology 37(1):83-117.

Ingels, S. .. et al. 2011. High School Longitudinal Study of 2009 (HSLS:09) Base-Year Data File Documentation (NCES 2011-328). Washington, D.C.: National Center for Education Statistics, Institute of Education Sciences, United States Department of Education.

Irizarry, Yasmiyn. 2015a. "Selling Students Short: Racial Differences in Teachers' Evaluations of High, Average, and Low Performing Students." Social Science Research 52:522-38.

Irizarry, Yasmiyn. 2015b. "Utilizing Multidimensional Measures of Race in Education Research: The Case of Teacher Perceptions." Sociology of Race and Ethnicity 1(4):564-83.

Ispa-Landa, Simone and Jordan Conwell. 2015. "'Once You Go to a White School, You Kind of Adapt': Black Adolescents and the Racial Classification of Schools." Sociology of Education 88(1):1-19.

John, Nancy St. 1970. “The Validity of Children's Reports of Their Parents' Educational Level: A Methodological Note." Sociology of Education 43(3):255-69.

Jones, Lyle V., Ernest C. Davenport Jr., Aloha Bryson, Tanja Bekhuis, and Rebecca Zwick. 1986. "Mathematics and Science Test Scores as Related to Courses Taken in High School and Other Factors." Journal of Educational Measurement 23(3):197-208.

Kelly, Sean. 2009. "The Black-White Gap in Mathematics Course Taking." Sociology of Education 82(1):47-69.

Kerckhoff, Alan C., William M. Mason, and Sharon Sandomirsky Poss. 1973. "On the Accuracy of Children's Reports of Family Social Status.” Sociology of Education 46(2):219-47.

Kornrich, Sabino and Frank Furstenberg. 2013. "Investing in Children: Changes in Parental Spending on Children, 1972-2007.” Demography 50(1):1-23.

Ladson-Billings, Gloria. 2006. "From the Achievement Gap to the Education Debt: Understanding Achievement in U.S. Schools.” Educational Researcher 35(7):3-12.

Ladson-Billings, Gloria. 2007. "Pushing Past the Achievement Gap: An Essay on the Language of Deficit." The Journal of Negro Education 76(3):316-23. Retrieved (https://www.jstor.org/stable/40034574).

Lareau, Annette and Erin McNamara Horvat. 1999. "Moments of Social Inclusion and Exclusion Race, Class, and Cultural Capital in Family-School Relationships." Sociology of Education (1):37-53. Retrieved (https://www.jstor.org/stable/2673185?origin=crossref).

Lemieux, Thomas. 2006. "Postsecondary Education and Increasing Wage Inequality." American Economic Review 96(2):195-99. 
Lewis-McCoy, R.L'Heureux. 2014. Inequality in the Promised Land: Race, Resources, and Suburban Schooling. Stanford, CA: Stanford University Press.

Lewis, Amanda E. and John B. Diamond. 2015. Despite the Best Intentions: How Racial Inequality Thrives in Good Schools. New York: Oxford University Press.

Looker, E.Dianne. 1989. "Accuracy of Proxy Reports of Parental Status Characteristics." Sociology of Education 62(4):257-76.

López, Nancy, Christopher Erwin, Melissa Binder, and Mario Javier Chavez. 2018. "Making the Invisible Visible: Advancing Quantitative Methods in Higher Education Using Critical Race Theory and Intersectionality." Race Ethnicity and Education 21(2):180-207.

Magnuson, Katherine and Jane Waldfogel. 2008. "Introduction." Pp. 1-29 in Steady Gains and Stalled Progress: Inequality and the Black-White Test Score Gap, edited by K. Magnuson and J. Waldfogel. New York: Russell Sage Foundation.

Massey, Douglas S. and Stefanie Brodmann. 2014. Spheres of Influence: The Social Ecology of Racial and Class Inequality. New York: Russell Sage Foundation.

McCall, Leslie. 2005. "The Complexity of Intersectionality.” Signs 30(3):1771-1800.

McLanahan, Sara and Christine Percheski. 2008. "Family Structure and the Reproduction of Inequality." Annual Review of Sociology 34:257-76.

Murnane, Richard J. and Sean F. Reardon. 2018. "Long-Term Trends in Private School Enrollments by Family Income.” AERA Open 4(1):1-24.

Orr, Amy J. 2003. "Black-White Differences in Achievement: The Importance of Wealth." Sociology of Education 76(4):281-304.

Owens, Ann. 2018. "Income Segregation between School Districts and Inequality in Students' Achievement." Sociology of Education 91(1):1-27.

Owens, Ann, Sean F. Reardon, and Christopher Jencks. 2016. "Income Segregation Between Schools and School Districts.” American Educational Research Journal 53(4):1159-97.

Pfeffer, Fabian T. 2018. “Growing Wealth Gaps in Education.” Demography 55(3):1033-68.

Phillips, Meredith, Jeanne Brooks-Gunn, Greg J. Duncan, Pamela Klebanov, and Jonathan Crane. 1998. "Family Background, Parenting Practices, and the Black-White Test Score Gap.” Pp. 103-45 in The Black-White Test Score Gap, edited by C. Jencks and M. Phillips. Washington, D.C.: Brookings Institution Press.

Phillips, Meredith, James Crouse, and John Ralph. 1998. "Does the Black-White Test Score Gap Widen after Children Enter School.” Pp. 229-72 in The Black-White Test Score Gap, edited by C. Jencks and M. Phillips. Washington, D.C.: Brookings Institution Press. 
Porter, Eduardo. 2015. "Education Gap Between Rich and Poor Is Growing Wider." New York Times, September 22, B1. Retrieved

(https://www.nytimes.com/2015/09/23/business/economy/education-gap-between-rich-andpoor-is-growing-wider.html).

Quadlin, Natasha and Jordan A. Conwell. 2020. "Race, Gender, and Parental College Savings: Assessing Economic and Academic Factors.” Sociology of Education 1-23.

Quinn, David M. 2015. "Kindergarten Black-White Test Score Gaps: Re-Examining the Roles of Socioeconomic Status and School Quality with New Data." Sociology of Education 88(2):120-39.

Ray, Victor. 2019. “A Theory of Racialized Organizations.” American Sociological Review $0(0): 1-28$.

Reardon, Sean F. 2011. "The Widening Academic Achievement Gap Between the Rich and the Poor: New Evidence and Possible Explanations." Pp. 91-116 in Whither Opportunity?

Rising Inequality, Schools, and Children's Life Chances, edited by G. J. Duncan and R. J. Murnane. New York: Russell Sage Foundation.

Reardon, Sean F. and Ximena A. Portilla. 2016. "Recent Trends in Income, Racial, and Ethnic School Readiness Gaps at Kindergarten Entry." AERA Open 2(3):1-18.

Reardon, Sean F., Joseph P. Robinson-Cimpian, and Ericka S. Weathers. 2014. "Patterns and Trends in Racial/Ethnic and Socioeconomic Academic Achievement Gaps." Pp. 491-509 in Handbook of Research in Education Finance and Policy, edited by H. A. Ladd and E. B. Fiske. New York: Routledge.

Riegle-Crumb, Catherine and Barbara King. 2010. "Questioning a White Male Advantage in STEM: Examining Disparities in College Major by Gender and Race/ Ethnicity." Educational Researcher 39(9):656-64.

Rock, D. A. et al. 1985. Psychometric Analysis of the NLS and the High School and Beyond Test Batteries. Washington, D.C.: National Center for Education Statistics, United States Department of Education.

Roscigno, Vincent J. 2000. "Family/School Inequality and African-American/Hispanic Achievement." Social Problems 47(2):266-90.

Roscigno, Vincent J. 1998. "Race and the Reproduction of Educational Disadvantage." Social Forces 76(3):1033-60.

Rothstein, Jesse and Nathan Wozny. 2013. "Permanent Income and the Black-White Test Score Gap.” Journal of Human Resources 48(3):509-44. 
Royston, Patrick. 2005. "Multiple Imputation of Missing Values: Update of Ice." The Stata Journal 5(4):527-36.

Schneider, Daniel, Orestes P. Hastings, and Joe LaBriola. 2018. "Income Inequality and Class Divides in Parental Investments." American Sociological Review 83(3):475-507.

Sharkey, Patrick. 2014. "Spatial Segmentation and the Black Middle Class." American Journal of Sociology 119(4):903-54. Retrieved (https://doi.org/10.1086/674561).

Sharkey, Patrick and Felix Elwert. 2011. "The Legacy of Disadvantage: Multigenerational Neighborhood Effects on Cognitive Ability." American Journal of Sociology 116(6):193481.

Stewart, Quincy Thomas and Abigail A. Sewell. 2011. "Quantifying Race: On Methods for Analyzing Social Inequality.” Pp. 209-34 in Rethinking Race and Ethnicity in Research Methods, edited by J. H. Stanfield II. Walnut Creek, CA: Left Coast Press, Inc.

Tyson, Karolyn. 2011. Integration Interrupted: Tracking, Black Students and Acting White after Brown. New York: Oxford University Press.

U.S. Census Bureau. 1999. Statistical Abstract of the United States: 1999. Washington, D.C. Retrieved (https://www.census.gov/prod/99pubs/99statab/sec04.pdf).

United States Department of Education. 2001. High School and Beyond, 1980: A Longitudinal Survey of Students in the United States [Computer File]. Ann Arbor, MI: Inter-university Consortium for Political and Social Research [Distributor].

Valant, Jon and Daniel A. Newark. 2016. "The Politics of Achievement Gaps." Educational Researcher 45(6):331-46.

Yeung, Wei-Jun Jean and Kathryn M. Pfeiffer. 2009. "The Black-White Test Score Gap and Early Home Environment.” Social Science Research 38(2):412-37.

Zuberi, Tukufu. 2001. Thicker than Blood: How Racial Statistics Lie. University. Minneapolis, MN.

Zuberi, Tukufu and Eduardo Bonilla-Silva, eds. 2008. White Logic, White Methods: Racism and Methodology. Lanham, MD: Rowman \& Littlefield Publishers, Inc. 


\section{AUTHOR BIORGRAPHY}

Jordan A. Conwell is an Assistant Professor in the Departments of Sociology and Educational Policy Studies at the University of Wisconsin-Madison. His research focuses on trends and consequences of racial, social class, and gender inequality in education, with a particular interest in the multigenerational roles of families and finances in these educational processes, as inputs for children and as outputs for adults. His recent studies have appeared in journals including Journal of Marriage and Family, Sociology of Education, and Urban Education. He completed a Ph.D. in Sociology at Northwestern University in 2017. During the 2020-2021 academic year, he will be a National Academy of Education/ Spencer Foundation Postdoctoral Fellow. 


\section{ONLINE APPENDIX A. DEFINITIONS OF VARIABLES USED}

\begin{tabular}{|c|c|c|}
\hline Variable & $\begin{array}{l}\text { Source(s) of } \\
\text { Information }\end{array}$ & Relevant Information Regarding Question Text, Response Categories, and/ or Coding \\
\hline Race & Student & $\begin{array}{l}1=\text { ="Black or Negro or Afro American" } \\
0=\text { "White or Caucasian" } \\
\text { Note: See Appendix B for details on imputation procedure for race in Project TALENT. }\end{array}$ \\
\hline Math Achievement & Student & Student's combined three-part math score (arithmetic reasoning, introductory mathematics, and advanced mathematics) \\
\hline Income & Student & $\begin{array}{l}\text { Reported in five categories: } \\
\text { Less than } \$ 3,000 \\
\$ 3,000-\$ 6,000 \\
\$ 6,000-\$ 8,999 \\
\$ 9,000-\$ 11,999 \\
\$ 12,000 \text { or more }\end{array}$ \\
\hline Mother's Education (Years) & Student & $\begin{array}{l}\text { Coded to years based on student's report of mother's educational attainment: } \\
\text { None or some grade school }=6 \\
\text { Completed grade school }=8 \\
\text { Some high school but did not graduate }=10 \\
\text { Graduated high school }=12 \\
\text { Vocational or business school after high school }=14 \\
\text { Some junior or regular college but did not graduate }=14 \\
\text { Graduated from regular four-year college }=16 \\
\text { Master's degree }=18 \\
\text { Some work towards doctoral or professional degree }=19 \\
\text { Completed doctoral or professional degree }=21\end{array}$ \\
\hline Two-Parent Household & Student & $\begin{array}{l}1=\text { living with mother and father, mother and stepfather, father and stepmother, or foster parents (not relatives) } \\
0=\text { all other arrangements }\end{array}$ \\
\hline Family Size & Student & "Total number of living children in your family," including those not now living in the home \\
\hline Mother's Age at Child's Birth & Student & Mother's age (taken from midpoints of student's categorical responses) minus student's age \\
\hline Percentage Economically Disadvantaged Students in School & Created & $\begin{array}{l}\text { Percentage of students with the given school ID who reported family incomes in the lowest category (Less than } \$ 3,000 \text { ). } \\
\text { Note: This income value maps neatly onto the } 1959 \text { poverty threshold for a family of four. }\end{array}$ \\
\hline Percentage Black (White) Students in School & School Administrator & $\begin{array}{l}\text { "About what percentage of your grades 9-12 pupils are Negro?" Response categories were deciles, coded to midpoint. Coded as } 100 \text { if } \\
\text { administrator indicated "all." Administrators were not asked to provide the percentage of White students in their schools, The variable for } \\
\text { percentage of White students is created, as } 100 \text { percent minus the racial/ ethnic groups administrators were asked about (Black, Spanish, } \\
\text { Oriental, Indian). }\end{array}$ \\
\hline
\end{tabular}




\begin{tabular}{|c|c|c|}
\hline Variable & $\begin{array}{l}\text { Source(s) of } \\
\text { Information }\end{array}$ & Relevant Information Regarding Question Text, Response Categories, and/ or Coding \\
\hline Race & Student & $\begin{array}{l}1=\text { ="Black" } \\
0=\text { "White" }\end{array}$ \\
\hline Math Achievement & Student & Part I of math assessment \\
\hline Income & Student & $\begin{array}{l}\text { Reported in seven categories: } \\
\text { Under } \$ 7,000 \\
\$ 7,000-\$ 12,000 \\
\$ 12-000-\$ 16,000 \\
\$ 16,000-\$ 20,000 \\
\$ 20,000-\$ 25,000 \\
\$ 25,000-\$ 38,000 \\
\text { Over } \$ 38,000\end{array}$ \\
\hline Mother's Education (Years) & Student & $\begin{array}{l}\text { Coded to years based on student's report of mother's educational attainment: } \\
\text { Below high school }=8 \\
\text { High school graduate }=12 \\
\text { Vocational school less than two years }=13 \\
\text { Vocational school two or more years }=14 \\
\text { College less than two years }=13 \\
\text { College two or more years }=14 \\
\text { College graduate }=16 \\
\text { Master's degree }=18 \\
\text { Ph.D., M.D., or advanced degree }=21\end{array}$ \\
\hline Two-Parent Household & Student & $\begin{array}{l}1=\text { living with mother and father, mother and other male guardian, father and other female guardian, or other male and other female } \\
0=\text { all other arrangements }\end{array}$ \\
\hline Family Size & Student & $\begin{array}{l}\text { Summed responses to five categories, each top-coded at five if student indicated "five or more" in a given category: } \\
\text { Siblings three or more years older (zero - "five or more") } \\
\text { Siblings one to two years older (zero - "five or more") } \\
\text { Siblings same age as you (zero - "five or more") } \\
\text { Siblings one to two years younger (zero - "five or more") } \\
\text { Siblings three or more years younger (zero - "five or more") }\end{array}$ \\
\hline Percentage Economically Disadvantaged Students in School & School Administrator & $\begin{array}{l}\text { "About what percentage of the students in your high school are classified as disadvantaged?" } \\
\text { Note: On the school administrator questionnaire, the above question (SB037) was preceded by the following question (SB036): "Please indicate } \\
\text { whether or not your school uses each of the following criteria to classify students as disadvantaged." Response options were federal guidelines } \\
\text { ( } 803 / 988 \text { administrators indicated yes), state guidelines (773/988 administrators indicated yes), and other means (340/988 administrators } \\
\text { indicated yes). The text for question SB037 does not indicate which set of guidelines administrators used to formulate their responses. }\end{array}$ \\
\hline Percentage Black (White) Students in School & School Administrator & "Approximately what percentage of your current high school students are Black, not of Hispanic origin (White)?" \\
\hline
\end{tabular}


Online Appendix Table A3. Definitions of Variables Used for High School Longitudinal Study (2009)

\begin{tabular}{|c|c|c|}
\hline Variable & $\begin{array}{l}\text { Source(s) of } \\
\text { Information }\end{array}$ & Relevant Information Regarding Question Text, Response Categories, and/ or Coding \\
\hline Race & Student & $\begin{array}{l}1=\text { "Black/ African-American, non-Hispanic" } \\
0=\text { "White, non-Hispanic" }\end{array}$ \\
\hline Math Achievement & Student & Math assessment in algebraic reasoning \\
\hline Income & Parent & $\begin{array}{l}\text { Reported in } 13 \text { categories: } \\
\text { Less than or equal to } \$ 15,000 \\
\$ 15,000-\$ 35,000 \\
\$ 35,000-\$ 55,000 \\
\$ 55,000-\$ 75,000 \\
\$ 75,000-\$ 95,000 \\
\$ 95,000-\$ 115,000 \\
\$ 115,000-\$ 135,000 \\
\$ 135,000-\$ 155,000 \\
\$ 155,000-\$ 175,000 \\
\$ 175,000-\$ 195,000 \\
\$ 195,000-\$ 215,000 \\
\$ 215,000-\$ 235,000 \\
\text { Greater than } \$ 235,000\end{array}$ \\
\hline Mother's Education (Years) & Parent & $\begin{array}{l}\text { Coded to years based on responding parent's report of student's mother's/ female guardian's highest level of education: } \\
\text { Less than high school }=8 \\
\text { High school diploma or GED }=12 \\
\text { Associate's degree }=14 \\
\text { Bachelor's degree }=16 \\
\text { Master's degree }=18 \\
\text { Ph.D./ M.D. } / \text { Law/ other high-level professional degree }=21\end{array}$ \\
\hline Two-Parent Household & Parent & $\begin{array}{l}1=\text { responding parent indicated that they have a spouse or partner who lives in the household } \\
0=\text { responding parent indicated that they do not have such a spouse or partner }\end{array}$ \\
\hline Family Size & Parent & "How many people in your household are under the age of $18 ? "$ \\
\hline Mother's Age at Child's Birth & Parent and Student & $\begin{array}{l}\text { Mother's age obtained from parent report, if responding parent indicated they were student's biological mother, minus student's age obtained } \\
\text { from their response to student questionnaire. }\end{array}$ \\
\hline Percentage Economically Disadvantaged Students in School & School Administrator & "What percentage of the total student body in your school receives free or reduced-price lunch?" \\
\hline Percentage Black (White) Students in School & School Administrator & "What percentage of the total student body in your school are Black or African American, non-Hispanic (White)?" \\
\hline
\end{tabular}




\section{ONLINE APPENDIX B. IMPUTATION OF RACE FOR BASE YEAR OF PROJECT TALENT (1960)}

Project TALENT did not ask base year respondents to provide their race, but it did ask first follow-up respondents to do so.

Therefore, in the base year freshmen class data that I use for my analyses, I am only able to verify race, based on a respondent report, for those who also responded to the first follow-up. I drop those respondents whose first follow-up race is recorded as "Oriental"

(264), “American Indian” (35), "Mexican American" (105), or "Puerto Rican American” (8). This leaves 103,390 students. Of those, 34,489 are recorded as "White or Caucasian" and 1,883 are recorded as "Black or Negro or Afro American." In Appendix Table B1, below, the column for Stage 1 reports the Black-White math test score disparity among these students, for those who had a nonmissing math test score. This procedure leaves 67,018 students whose race I cannot verify based on a respondent report. For these remaining students, I imputed race based on the procedure described below, assuming that students are either Black or White. 
Online Appendix Table B1. Black-White Math Test score disparities for Project TALENT Base Year Freshmen at Successive Stages of Race Imputation Procedure

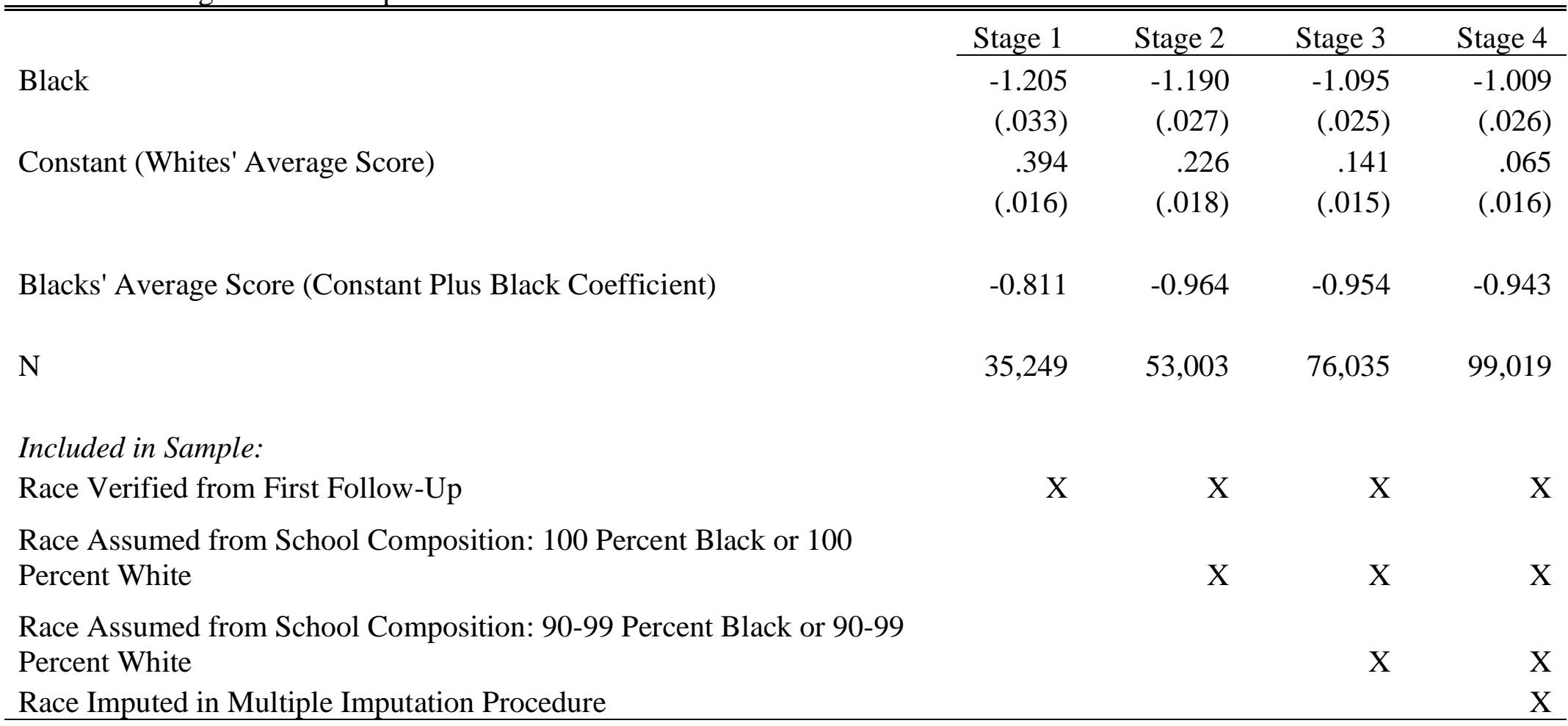

Notes: Standard errors (in parentheses) are adjusted for clustering of students within schools. Coefficients refer to standard deviation units (see text for details on standardization procedure). Estimates are weighted with the base year sampling weight. Estimates are not adjusted for measurement error in the math test instrument. 
Project TALENT asked school administrators to provide figures on the racial composition of their schools in the base year. For students' whose school administrators provided this information, I was able to assume many students' races based on their schools' racial composition. An additional 4,200 students whose race was not available in the base year data attended schools whose administrators reported student bodies that were 100 percent Black. I assigned such students' races as Black. An additional 14,391 students whose race was not available in the base year data attended schools whose administrators reported student bodies that were 100 percent White. Administrators were not asked to provide a figure for the percentage of White students in their schools. I assumed a school's student body was 100 percent White if the administrator reported that the school's percentages of "Black," "Spanish," "Oriental," and "Indian" students were all zero (see also Karr 2014). A total of 5,066 students attended schools in which the administrator did not report a student body composition for any of the four racial/ ethnic groups. For these students, I do not assume race based on school composition. Administrators were also asked to report their schools' percentages of students in 'Other 'Minority' Group (specify)." I do not use this information in the race imputation procedure. Karr (2014: 2) notes that "it is clear that some schools interpreted this to mean religious minorities in addition to or instead of racial minorities." I assigned such students' races as White. In Appendix Table B1, the column for Stage 2 reports the Black-White math test score disparity among the sample including these students, for those who had a nonmissing math test score. Compared to results for Stage 1, in Stage 2, both Blacks' and Whites' average scores decrease by about .150 standard deviations (SDs), leaving a Black-White math gap that is similar in magnitude to the one from the previous stage. For both Blacks and Whites, changes in average scores across Stages 1 and 2 are broadly consistent with 
a common survey nonresponse bias mechanism, which supports the hypothesis that, on average, those who respond to a follow-up study are often advantaged relative to those who cannot be found or do not respond (Armstrong and Overton 1977).

Based on those same two variables for school racial composition, I assigned an additional 571 students' races as Black and 23,584 students' races as White based on attending a school that was between 90 and 99 percent of the respective race. In Appendix Table B1, the column for Stage 3 reports the Black-White math test score disparity among the sample including these students, for those who had a nonmissing math test score. Compared to results for Stage 2, Whites' average score decreases by an additional .085 SDs, while Blacks' average score is relatively unchanged, leaving a Black-White gap (-1.095 SDs) that is approximately one-tenth of a SD smaller than the one at the previous stage. It is possible that, on average, the White students who enter the sample based on their school having between 90 and 99 percent White students are less advantaged than those whose schools are 100 percent White.

For the remaining students who had a nonmissing math score in the base year data, I imputed race in the multiple imputation procedure. In Appendix Table B1, the column for Stage 4 reports the Black-White math test score disparity among the sample including these students. Compared to the results for Stage 3, Whites' average score again decreases, by .076 SDs, while Blacks' average score is again relatively unchanged. These patterns result in a Black-White math gap of -1.009 SDs, which is 16.266 percent smaller than the gap among those whose race I verified based on data from the first follow-up (Stage 1). Particularly when it is adjusted for measurement error in the math test instrument (reliability $=.75$, adjusted gap $=-1.165$ ), this figure is comparable to the Black-White math test score disparities for the four Project TALENT classes that Reardon (2011, Figure 5.4) reports, all of which fall between 1.00 and 1.25 SDs. 


\section{REFERENCES FOR ONLINE APPENDIX B}

Armstrong, J.Scott and Terry S. Overton. 1977. "Estimating Nonresponse Bias in Mail Surveys.” Journal of Marketing Research 14(3):396. Retrieved (https://www.jstor.org/stable/3150783?origin=crossref).

Karr, Alan F. 2014. Multiple Imputation of Race for Project TALENT (Technical Report 187). Research Triangle Park, NC. Retrieved (https://www.niss.org/sites/default/files/tr187.pdf).

Reardon, Sean F. 2011. "The Widening Academic Test score disparity Between the Rich and the Poor: New Evidence and Possible Explanations." Pp. 91-116 in Whither Opportunity? Rising Inequality, Schools, and Children's Life Chances, edited by G. J.

Duncan and R. J. Murnane. New York: Russell Sage Foundation. 
Online Appendix C. Numbers of Observations and Cumulative Percentages for Income Percentile Bins (Pooled Income Distribution), by Race and Year

\begin{tabular}{|c|c|c|c|c|}
\hline \multirow{3}{*}{$\begin{array}{c}\text { Income } \\
\text { Percentile }\end{array}$} & \multicolumn{2}{|c|}{ Whites } & \multicolumn{2}{|r|}{ Blacks } \\
\hline & \multicolumn{3}{|c|}{ Cumulative } & \multirow{2}{*}{$\begin{array}{l}\text { Cumulative } \\
\text { Percentage }\end{array}$} \\
\hline & $\mathrm{N}$ & Percentage & $\mathrm{N}$ & \\
\hline \multicolumn{5}{|c|}{ 1960: Project TALENT } \\
\hline 1 & 11,332 & 12.38 & 1,929 & 25.75 \\
\hline 12 & 31,627 & 46.94 & 2,118 & 54.02 \\
\hline 43 & 32,923 & 82.91 & 2,287 & 84.54 \\
\hline 72 & 8,873 & 92.60 & 831 & 95.63 \\
\hline 87 & 6,772 & 100 & 327 & 100 \\
\hline
\end{tabular}

1980: High School and Beyond

$\begin{array}{rrrrr}1 & 1,169 & 5.6 & 654 & 17.79 \\ 8 & 2,143 & 15.87 & 851 & 40.94 \\ 19 & 3,720 & 33.69 & 637 & 58.28 \\ 37 & 4,281 & 54.20 & 533 & 72.77 \\ 56 & 3,535 & 71.13 & 446 & 84.90 \\ 75 & 3,095 & 85.96 & 264 & 92.09 \\ 89 & 2,932 & 100 & 291 & 100\end{array}$

2009: High School Longitudinal Study

\begin{tabular}{rrrrr}
1 & 520 & 10 & 400 & 30 \\
10 & 1,300 & 20 & 510 & 60 \\
28 & 1,550 & 40 & 270 & 80 \\
44 & 1,570 & 50 & 170 & 90 \\
60 & 1,230 & 70 & 80 & 90 \\
71 & 980 & 80 & 50 & 90 \\
80 & 600 & 80 & 40 & 100 \\
86 & 520 & 90 & 10 & 100 \\
90 & 240 & 90 & 10 & 100 \\
93 & 150 & 90 & 0 & 100 \\
94 & 200 & 90 & 10 & 100 \\
96 & 530 & 100 & 20 & 100 \\
\hline
\end{tabular}

Notes: The number of percentile "bins" differs across surveys, based on the number of response categories that each survey's categorical income question offered to respondents. Numbers of observations (and percentages based on them) in High School Longitudinal Study rounded to nearest ten, per NCES guidelines. 
Online Appendix D. Linear Regressions of Math Test Score on Race, Cubic Function of Parental Income Percentile, Their Interactions, and Family and School Characteristics (Also Interacted with Income Terms, Not Shown)

\begin{tabular}{|c|c|c|c|c|c|c|c|c|c|}
\hline \multirow{3}{*}{ Income Percentile } & Family & School & Both & Family & School & Both & Family & School & Both \\
\hline & 0.064 & 0.094 & 0.067 & $0.128^{* *}$ & 0.059 & 0.087 & 0.159 & $0.166^{*}$ & 0.154 \\
\hline & $(0.040)$ & $(0.048)$ & $(0.041)$ & $(0.048)$ & $(0.050)$ & $(0.047)$ & $(0.092)$ & $(0.081)$ & $(0.087)$ \\
\hline \multirow[t]{2}{*}{ Income Percentile Squared } & -0.002 & -0.002 & -0.002 & $-0.004 * *$ & -0.002 & $-0.003^{*}$ & -0.004 & -0.004 & -0.004 \\
\hline & $(0.001)$ & $(0.001)$ & $(0.001)$ & $(0.001)$ & $(0.001)$ & $(0.001)$ & $(0.002)$ & $(0.002)$ & $(0.002)$ \\
\hline \multirow[t]{2}{*}{ Income Percentile Cubed } & 0.000 & 0.000 & 0.000 & $0.000^{* *}$ & 0.000 & $0.000 *$ & 0.000 & 0.000 & 0.000 \\
\hline & $(0.000)$ & $(0.000)$ & $(0.000)$ & $(0.000)$ & $(0.000)$ & $(0.000)$ & $(0.000)$ & $(0.000)$ & $(0.000)$ \\
\hline \multirow[t]{2}{*}{ Black } & $-0.744 * * *$ & $-0.112 * * *$ & $-0.093 * *$ & $-0.465 * * *$ & $-0.304 * * *$ & $-0.280 * * *$ & $-0.307 * * *$ & -0.183 & -0.173 \\
\hline & $(0.027)$ & $(0.029)$ & $(0.029)$ & $(0.050)$ & $(0.057)$ & $(0.062)$ & $(0.085)$ & $(0.100)$ & $(0.098)$ \\
\hline \multirow[t]{2}{*}{ Black X Income Percentile } & -0.002 & -0.005 & -0.004 & $-0.015^{*}$ & -0.008 & -0.008 & -0.006 & -0.013 & -0.015 \\
\hline & $(0.004)$ & $(0.004)$ & $(0.003)$ & $(0.006)$ & $(0.008)$ & $(0.008)$ & $(0.010)$ & $(0.010)$ & $(0.010)$ \\
\hline Black X Income Percentile Squared & $(0.000)$ & $(0.000)$ & $(0.000)$ & $(0.000)$ & $(0.000)$ & $(0.000)$ & $(0.000)$ & $(0.000)$ & $(0.000)$ \\
\hline \multirow[t]{2}{*}{ Black X Income Percentile Cubed } & -0.000 & -0.000 & -0.000 & -0.000 & -0.000 & -0.000 & -0.000 & -0.000 & -0.000 \\
\hline & $(0.000)$ & $(0.000)$ & $(0.000)$ & $(0.000)$ & $(0.000)$ & $(0.000)$ & $(0.000)$ & $(0.000)$ & $(0.000)$ \\
\hline \multirow[t]{2}{*}{ Female } & $-0.050 *$ & $-0.064 * * *$ & $-0.057 * *$ & -0.047 & -0.057 & -0.042 & 0.144 & 0.092 & 0.088 \\
\hline & $(0.020)$ & $(0.016)$ & $(0.018)$ & $(0.041)$ & $(0.042)$ & $(0.039)$ & $(0.086)$ & $(0.086)$ & $(0.084)$ \\
\hline \multirow[t]{2}{*}{ Age } & $-0.190 * * *$ & $-0.193 * * *$ & $-0.173^{* * *}$ & $-0.188 * * *$ & $-0.180^{* * *}$ & $-0.165^{* * *}$ & $-0.128 *$ & $-0.116^{*}$ & -0.099 \\
\hline & $(0.018)$ & $(0.020)$ & $(0.017)$ & $(0.027)$ & $(0.027)$ & $(0.025)$ & $(0.051)$ & $(0.050)$ & $(0.050)$ \\
\hline \multirow[t]{2}{*}{ Mother's Education (Years) } & $0.033 * * *$ & & $0.023 * * *$ & $0.066^{* * *}$ & & $0.048 * * *$ & $0.058 * * *$ & & $0.034 *$ \\
\hline & $(0.004)$ & & $(0.003)$ & $(0.010)$ & & $(0.009)$ & $(0.018)$ & & $(0.016)$ \\
\hline Two-Parent Household & $0.123 * * *$ & & $0.104 * * *$ & 0.055 & & 0.060 & 0.004 & & 0.022 \\
\hline Family Size & $(0.004)$ & & $(0.004)$ & $(0.009)$ & & $(0.008)$ & $(0.034)$ & & $(0.030)$ \\
\hline Percentage of Economically Disadvantaged Students in School & & $0.004 * * *$ & $0.005 * * *$ & & -0.000 & 0.000 & & -0.001 & -0.000 \\
\hline \multirow{2}{*}{ Percentage of White Students in School } & & -0.000 & -0.000 & & $-0.005^{* * *}$ & $-0.004 * * *$ & & -0.002 & -0.001 \\
\hline & & $(0.000)$ & $(0.000)$ & & $(0.001)$ & $(0.001)$ & & $(0.002)$ & $(0.002)$ \\
\hline \multirow[t]{2}{*}{ School Average Math Score (SDs) } & & $0.837 * * *$ & $0.797 * * *$ & & $0.877 * * *$ & $0.809 * * *$ & & $0.725 * * *$ & $0.720 * * *$ \\
\hline & & $(0.030)$ & $(0.030)$ & & $(0.067)$ & $(0.072)$ & & $(0.107)$ & $(0.106)$ \\
\hline \multirow[t]{2}{*}{ Constant } & $2.327 * * *$ & $2.699 * * *$ & $2.159 * * *$ & $1.930^{* * * *}$ & $2.975^{* * *}$ & $2.150 * * *$ & 0.701 & $1.571^{*}$ & 0.813 \\
\hline & $(0.281)$ & $(0.327)$ & $(0.274)$ & $(0.420)$ & $(0.446)$ & $(0.426)$ & $(0.835)$ & $(0.753)$ & $(0.821)$ \\
\hline Observations & 99,019 & 99,019 & 99,019 & 24,551 & 24,551 & 24,551 & 10,970 & 10,970 & 10,970 \\
\hline
\end{tabular}
Robust standard errors in parentheses. Numbers of observations for 2009 (High School Longitudinal Study) rounded to nearest 10, per National Center for Education Statistics guidelines.
$* * * p<.001 ; * * p<.01 ; * p<.05$ 
Online Appendix E. Marginal Effects of Black (Versus White) for Predicted Probabilities of Most Advanced Math Course Taken by 9th Grader in 8th Grade, by Parental Income Percentile, High School Longitudinal Study (2009)

\begin{tabular}{|c|c|c|c|c|c|c|}
\hline \multirow{2}{*}{$\begin{array}{l}\text { Math Course } \\
\text { Math } 8\end{array}$} & \multirow{2}{*}{$\begin{array}{l}\begin{array}{l}\% \text { of Full } \\
\text { Sample } \\
\text { (Weighted) }\end{array} \\
20.29\end{array}$} & $\begin{array}{c}\text { 10th } \\
\text { Percentile }\end{array}$ & \multicolumn{2}{|c|}{$\begin{array}{c}\text { 50th } \\
\text { Percentile }\end{array}$} & \multicolumn{2}{|c|}{$\begin{array}{c}\text { 90th } \\
\text { Percentile }\end{array}$} \\
\hline & & $-.05 *$ & .06 & $*$ & .06 & \\
\hline Advanced or Honors Math 8 & 2.07 & .00 & .00 & $* *$ & .01 & \\
\hline Pre-algebra & 35.58 & -.01 & .02 & $* * *$ & .05 & $*$ \\
\hline Algebra I including IA and IB & 32.42 & $.04 *$ & -.06 & $*$ & -.07 & \\
\hline Algebra II or Trigonometry & 0.81 & .00 & .00 & $* *$ & .00 & $*$ \\
\hline Geometry & 3.36 & .01 & -.01 & $* *$ & -.02 & $*$ \\
\hline Integrated Math & 1.72 & .00 & .00 & $* *$ & -.01 & $*$ \\
\hline Other Advanced Math Course (Pre-Calculus or Calculus) & 3.74 & .01 & -.01 & $* *$ & -.02 & $*$ \\
\hline Total & 100 & & & & & \\
\hline
\end{tabular}

Notes: $\mathrm{N}=10,830$ (rounded to nearest 10, per NCES guidelines for restricted-use data). Sample for this analysis includes students with non-missing information on race, parental income, gender, age, 8th grade math course, and 9th grade math score. Predicted probabilities are based on an ordinal logistic regression model (results not shown) that regresses 8th grade math course (response categories indicated in leftmost column of Table 4) on a cubic function of parental income percentile, with all three income terms interacted with race, gender, and age. Significance tests for marginal effects are based on robust standard errors. 